\title{
On the Institutional Roots of Swiss Democracy
}

\author{
Gkanas Nikitas", Kyriazis Nicholas \\ Department of Economics, University of Thessaly, Greece
}

Copyright $\bigcirc 2016$ by authors, all rights reserved. Authors agree that this article remains permanently open access under the terms of the Creative Commons Attribution License 4.0 International License.

\begin{abstract}
Looking back at the history of Switzerland, we can identify some structural changes in the economic, social and cultural environment, also in the spiritual perceptions and attitudes of citizens. These may constituted the basis for the creation of specific standards and played a crucial role in the political and economic course of the country. In this study we examine how institutions can explain the emergence and establishment of democracy in Switzerland. We investigate various aspects of human activity in Switzerland trend since the beginning of its emergence, in order to use the tool of macro-culture that includes shared values, norms and beliefs that characterize the members of a society. Important aspects in the country's history are opening trade passages, alliances, military tactics and religion. The standards and values spun from the above aspects were transferred gradually to the political field. Finally, it is highlighted that these values contributed decisively in forging a strong polity with robust elements of direct democracy.
\end{abstract}

Keywords Switzerland, Democracy, Macro-culture, Institutions, Values

\section{Introduction}

Switzerland is a country that has been fairly studied by researchers mainly because of its particular characteristics that no one can find easily in other places. The high GDP per capita, the use of direct democracy processes by the simultaneous presence of the federal system, the smooth coexistence of disparate linguistic and religious groups, the neutrality in wars, are some of the most important. The studies published to date mainly concern questions such as why a country with such characteristics is able to emerge and be sustained in world affairs [1,2], how to explain the harmonious coexistence of its citizens that carry different characteristics at language and religion [3,4], how direct democracy affects economic growth of Switzerland $[5,6,7,8,9]$. The emergence of democracy and its longstanding presence in Switzerland is something that, as far as we know, has not been investigated separately but only as part of the query how Switzerland was created.

The aim of this research is to explain the emergence and establishment of democracy in Switzerland through a synthetic compound of institutional variables. By the term institutional we mean institutions as North [10] defined: an enduring set of rules to ensure consistency of the social system, as the formal (business, syndicate unions, government bodies, local governments, schools), social structures (such as legal system, political system, language, money), informal institutions such convention rules ${ }^{1}$, moral rules $^{2}$, habits ${ }^{3}$, social values ${ }^{4}$ (norms), cultural values (culture) and routines.

To achieve this synthesis we use the tools of macro-culture and bounded rationality. The macro-culture is a methodology that began very recently used in institutional economics $[11,12]$ and the political economy, whereas previously used for management science $[13,14,15]$ and psychology [16].

Looking back at the history of Switzerland, we can identify some structural changes in the economic, social and cultural environment, also in the spiritual perceptions and attitudes of citizens. These may constituted the basis for the creation of specific standards and played a crucial role in the political and economic course of the country.

Grouping the periods ${ }^{5}$ of history of the country, we can define as fields-milestones that established the 'school of Swiss thought/behavior' the following:

- Opening of (commercial) passes in the Alps,

- Alliances (cooperation at policy level).

- War (military tactics)

- Religion

The second part presents the materials and methods of the research containing the theoretical background of the implementation of macro-culture, bounded rationality and previous research, also the methodology and the historical

\footnotetext{
1 E.g. Rules of behavior-fair play

2 E.g. Trust, keep obligations

3 E.g. gifts

4 E.g. honesty, honor

5 Periods can be divided as following: $1^{\text {st }}: 1200-1291,2^{\text {nd }}: 1291-1386,3^{\text {rd }}$ :

$1386-1515,4^{\text {th. }}: 1515-1848$, according own process of historical evolution of the country.
} 
review, the third section shows the results analyzing the fields that determined the 'thought' of Switzerland, the fourth section composes the main findings of the third section, formatting the Swiss macro-culture and the fifth section concludes.

\section{Materials and Methods}

\subsection{Theoretical Background Literature Review}

Previous literature can be divided into two categories. Firstly, we can trace studies concerning macro-culture and transfer of values through bounded rationality in political or economical sectors and secondly historical studies for the state of Switzerland, during centuries, in a descriptive form.

The use of macro-culture appeared very recently in institutional economics (adapted from the organizational theory) as introduced in 2012, to investigate the relation between property rights and the values of democracy in the Bronze Age and the Archaic Greece [11] and to interpret the creation of cooperative companies formed private cruisers of England and the United Provinces (the Netherlands) in the late 16th century and early 17 th century [12]. A macro-culture is a set of common values, norms and beliefs that characterize the members of a society or a state.

The values are beliefs about what is right and wrong and what is important in life [17]. The norms are the rules of behaviour adopted by the majority, or at least receive the consent of a group about how they should individuals behave. The norms differ from personal values, as applicable to groups rather than individuals [18]. Examples in modern society are the norms of politeness, fairness, proper attire, proper behaviour in business meetings, equal treatment of the genders, body language and tone of voice of police officers during their duties.

Macro-culture is the set of values and symbols that can be applied to a society or to most of its citizens. Unlike the micro-culture is a set of values and symbols of a particular group of citizens or consumer's segment [18]. Macro culture, when adjusting the dimension of both economy and politics, includes also the characteristic of time (dynamic process) and it is studied mainly for long periods of time. The elements of macro-culture take shape over periods of decades or centuries [12].

Through these values, norms and beliefs, a macro-culture guides actions and creates typical behaviour among independent entities, so that it coordinates their activities so that complex tasks may be completed [13,14,15]. This happens in three ways: 1) by creating 'convergence of expectations', 2) by allowing for idiosyncratic language to summarize complex routines and information and 3) by specifying broad tacitly understood rules for appropriate actions under unspecified contingencies $[19,20,21]$. The establishment of 'communication protocols' follows.

Reference [15] has applied this concept to firms, while Almond and Verba [22] have written on 'civic culture' as a shared set of beliefs among citizens. Reference [23] argues that democratic stability depends on specific forms of social organization and citizen values which he calls 'civic traditions'. A similar line of argumentation [24] maintains that a structural embeddedness is developed: e.g., firms develop connected mutual contacts to one another. This corresponds to the establishment of mutual links or networks. These interactions define values and norms and thus strengthen this interdependence, the macro-culture. This is consistent with Lazaric [25], who claims that 'every recurrent interaction pattern in an organization may be hiding a potential routine' as well as with Vromen [26], who labels these mutual values, norms and patterns of behavior as 'routines' by depicting them as 'multilevel mechanisms' that generate firm behavior.

Reference [27] argues that economic activity is embedded in social institutions, customs and attitudes, while embeddedness of institutions in a historic and social context is a main idea of North's work $[28,10,29,30]$. In fact, this discussion of embeddedness is much older in the historical than in the organizational and economics context. It goes back to the 'Bücher-Meyer controversy' (the modernists versus the primitivists) concerning the ancient economy $[31,32,33]$. It was taken up again by scholars such as Polanyi [34], Humphreys [35] and Finley [36] who argued that the ancient economy was embedded in the social, political and cultural context and so was primitive, a thesis that has been refuted by more recent studies concerning the economy, [31,37-45] who argue that the ancient Greek economy, and particularly that of Athens, functioned much like the economies and markets of today.

Two particular questions on this issue are, first, how does such a macro-culture develop and, second, do macro-cultures proceed along different paths, evolving different characteristics? Related to this is the issue of 'cause' and effect. Do values and norms pre-exist (and if so, why and how did they come about) and do they shape a particular macro culture, or is it the other way round, that is, does a macro-culture give rise to specific values and norms? Thus, an actual answer can be given only if we manage to establish chronological sequences of events.

References [46,47] have analyzed one aspect of macro-culture and norms and values, the emergence of a new type of warrior in Archaic Greece, the hoplite (named from his big round shield, the 'hoplon') and the new tactical formation, the phalanx, as coordination and cooperation mechanisms which give rise to specific mental attitudes, values and norms, even a specific language (e.g. clear commands for battle) and learning and knowledge. Even more, the new warship adopted during the early 5 th century by the Greeks, the trireme and the naval fleets, developed and fine-tuned the cooperation and coordination mechanism in the phalanx's 'customs' values and norms. The next issue is why and how these norms and values are diffused from one sector of the macroculture into another, making it a coherent whole.

According to Kyriazis and Economou [12] the answer 
can be found in the theory of bounded rationality. References [48,49] developed the theory of bounded rationality, which states that the mind has limitations, for example in its capacity to absorb and use new information. We are not totally 'rational' in the sense of seeking to maximize utility or any other 'ideal'. What we actually do in real life is try to reach a solution that satisfies us even if it is not the best possible one. We may even ignore the best possible one that would maximize utility. Simon $[48,49]$ calls this behaviour 'satisficing' (deriving from the words satisfy and efficient). Satisficing enables us to find acceptable solutions with minimal expenditure of time and effort, thus reducing transaction costs (as e.g. information costs). Such a behaviour has further consequences: once we have found solutions to a particular problem that are perceived as adequate, when facing a new problem we try to use the established and known rules of the thumb, the known knowledge we possess, in order to solve the new problem. Figure 1 shows the dynamic structural change from one (old) macro-culture (leading to an economic and political change in the long term) to a different (new) macro-culture. The continuous line of om in Figure 1 shows the path that old macro-culture would follow, in case it was still remained.

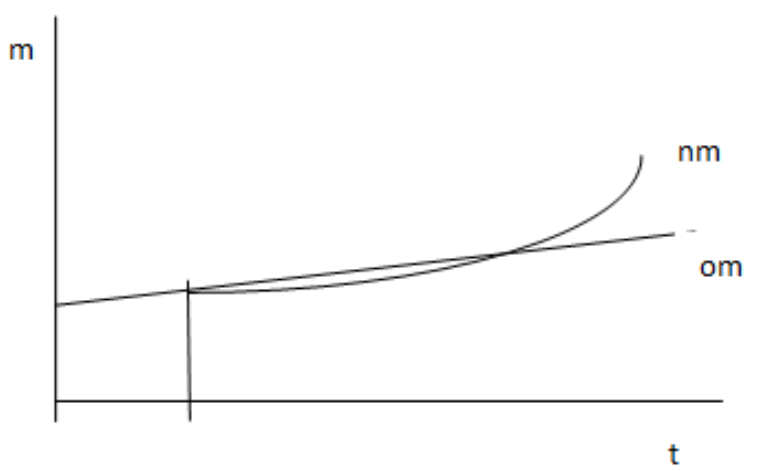

Source: Kyriazis and Metaxas [46]

Figure 1. Transition from the old to the new macro-culture

where:

m: macro-culture

t: time period

om: (old macro-culture): signifies the old macro-culture,

a system of norms, values and

customs etc. that characterize the economic, social and political field of a state and associated institutions and organizations.

$\mathrm{nm}$ : (new macro-culture): signifies the emerging new macro-culture, where new norms,

values, customs etc. are being created, developed and diffused, so that over time a break with the old path-macro-culture is accomplished, and the state follows a new path. We consider curve nm following an exponential shape because when during each period the state follows the new path $(\mathrm{nm})$, the probability of staying on the new path increases, and the probability of returning to the old path decreases (see table 1), because during each subsequent step along the new path, the various elements of the new macroculture are being mutually reinforced and integrated into a whole.

The model in Figure 1 can be described by two simple equations [50]:

$$
\mathrm{m}=\mathrm{om}+\mathrm{nm} * \mathrm{e}^{\mathrm{g}} \mathrm{t}^{* \mathrm{t}}
$$

Where m: the macroculture

om: old macroculture, which is the constant

$\mathrm{nm}$ : new macroculture, establishing over time if gt is positive.

$g_{t}$ : the rate of change depending on the creation of new elements of macroculture and their speed of diffusion (adaptation by other sectors).

A further elaboration could be made using (2).

$$
g_{t}=f(k, d)
$$

where:

$\mathrm{k}$ : knowledge

$\mathrm{d}$ : rate of diffusion (of the macro-culture effect)

We analyse in the text how the new values are diffused, through the working of bounded rationality, from one area of a macro-culture, to the others to form an interdependent and integrated whole. Having in mind that a process of a gradual structural socioeconomic conversion of a state can become feasible through the macro-culture effect, we can move from an old regime to one that creates new organizations and institutions. For instance, values and institutions such as inclusivity, cooperation, consent, equality, discipline, respect to diversity lead to fully developed democratic participation institutions, like that of referendum in Switzerland. We can describe this rate of change of 'learning' as depending on the rate of creation of new knowledge $k$, and the rate of its diffusion $d$.

So, the ultimate format of the macro-culture equation might be:

$$
\mathrm{m}=\mathrm{om}+\mathrm{nm} * \mathrm{e}^{\mathrm{f}(\mathrm{k}, \mathrm{d}) * \mathrm{t}}
$$

The conceptual framework presented in Figure 1 can also be described by Table 1. The latter shows the conditional probabilities; each one of the pn1, pn2......pnt corresponds to every next step along the new macroculture regime depending on the result of the previous period, and the probabilities 1-pn1, 1-pn2,...1-pnt show a return to the old macroculture regime. Based on the previous analysis we have:

$$
\begin{aligned}
\text { pn1 } & <\text { pn } 2<\ldots \ldots .<\text { pnt-1 }<\text { pnt } \\
1-\text { pn1 } & >1 \text {-pn2 }>\ldots \ldots>1 \text {-pnt-1 }>1-\text { pnt }
\end{aligned}
$$

Table 1. Decision Tree Probabilities

\begin{tabular}{|c|c|c|c|c|}
\hline $\begin{array}{c}\text { Time } \\
\text { period }\end{array}$ & 1 & 2 & $\cdots$ & $\mathrm{t}$ \\
\hline $\mathrm{Nm}$ & $p_{n 1}$ & $\begin{array}{c}p_{n 2} \\
=\left(p_{n 2} / p_{n 1}\right)\end{array}$ & $\cdots$ & $p_{n t}=\left(p_{n t} / p_{n t-1}\right)$ \\
\hline $\mathrm{Om}$ & $1-p_{n 1}$ & $1-p_{n 2}$ & $\ldots$ & $1-p_{n t}$ \\
\hline
\end{tabular}

Source: Kyriazis Nicholas and Metaxas Theodore [46] 
Equations (4) and (5) have a logical explanation. For instance, pn1 < pn2. This is valid because, as we have shown in Figure 1, when during each period the state follows the new path $(\mathrm{nm})$, the probability of staying into the new path (e.g. pn2) increases and is higher than the previous probability (e.g. pn1). So, it is clear that over time the probability of going back to the old macro-culture (1-pnt) converges towards zero. In Figure 2, we represent a decision tree, where the different elements of a macro-culture (e.g. religion, warfare, economy, politics etc.) are gradually being integrated into a new whole.

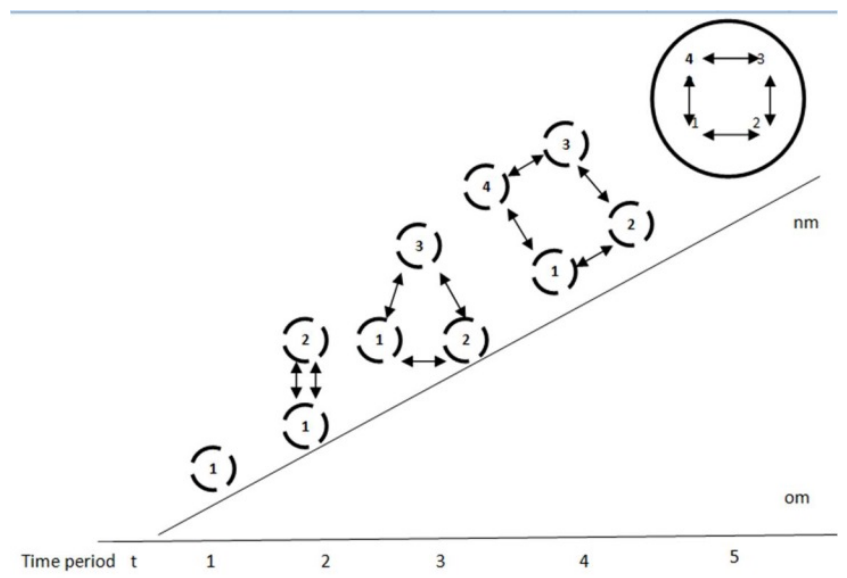

Source: Kyriazis and Metaxas [12]

Figure 2. Decision Tree and Integration of Various Elements of Macroculture

The circles represent the different elements of a new macro-culture, resulting in a field during the period 1 and 2 and amplified by dissemination to other areas in the periods 3 and 4 and have been consolidated into a new mutually supported macro-culture in period 5.

Having completed the review of the first category of the literature concerning macro-culture and transfer of values, we can address the second category of the literature. The second category includes studies that analyze the history of Switzerland as an entity, answering questions such as why the country was created and developed in high level economically and politically and what lessons could other countries gain $[1,2,51,4]$ and studies focusing in the analysis and description of the political system of direct democracy in Switzerland $[52,3,53,54]$.

According to Trechsel and Kriesi [55] the origins of direct democracy in Switzerland, begin a long time before the foundation of the Swiss Federation in 1848. One origin of direct democracy in Switzerland is traced back to the 12 th century $\mathrm{AD}$, in the medieval formations the people's government of communities, especially in the Italian-speaking part of today's Switzerland. The members of communities of Ticino, influenced by the development of communities in Northern Italy, have been gathered in so-called consiliums (councils) with main goal to resolve collectively all the pending problems of the community. At that time representatives of the Swiss cantons agreed to establish an alliance, which was enlarged over the centuries incorporating a large number of cantons. These cantons traditionally enabled men citizens to gather in the so-called general assembly (Landsgemeinde), an institution that is comparable to the assemblies of the early New England towns and the Ancient Greek Assemblies of the State People and remains active in two cantons until today ${ }^{6}$. A second origin of direct democracy institutions in Switzerland is the French Revolution. The ideas of the Enlightenment, especially the idea of people sovereignty, as well as the American experience with the constitutional referenda at state level, reached the Swiss cantons as the French Revolution was spreading in Europe. The first Swiss Constitution (1798), which was formed under the influence of the French Directorate, ruled that any constitutional amendment would be approved by corresponding mandatory referendum. Reference [54] highlights the Movement of Regeneration ${ }^{7}$ as an origin of direct democracy at the federal level. This liberal movement that began to activate in Switzerland immediately after the French Revolution in July 1830, was prominent in eleven cantons and triggered the introduction of the compulsory constitutional referendum, the legislative initiative or referendum and constitutional initiative, in most of them. Given the long tradition of having direct democracy institutions at cantonal level, the introduction of some of them at the federal level was only a matter of time.

\subsection{Methodology}

The methodology of macro-culture we use in this research can be analysed as follows: initially we set the fields-milestones seen in the historical evolution of Switzerland and the periods in which these fields appear. For each of the fields-milestones, values and institutions that contain democratic elements are detected. Then these values conveyed through bounded rationality to the political field and establish a regime of democracy. The values have been created in different but consecutive time periods, but each subsequent value shown coexists with the previous one and forms each time a synthetic macro-culture. When no other fields-milestones exist and detection of values and institutions is completed, the final macro-culture has been formatted/crystallised, leading to the establishment of democracy. In this research the time periods are divided into four, according to the historical evolution of Switzerland and literature, which are as follows: 1st: 1200-1291, 2nd: 1291-1386, 3rd: 1386-1515 4th: 1515-1848. Fields-milestones (analyzed in section 3) defined as trade passages, alliances, war tactics and religion, following the historical evolution the country.

6 The first recorded General Assembly (Landsgemeinde) can be traced back in 1294 in the canton of Schwyz [56].

7 The Revolution in July 1830, which annulled the sovereignty of the French King Charles the $10^{\text {th }}$, caused the Movement of Regeneration in Switzerland that promoted progressive ideas. Many of the cantons established representative elected parliaments, equality for all residents and freedom of the press, the trade and the industry [57]. 
The time periods are selected according to the facts occurred. Specifically the beginning of each period reflect the emergence of a fact (such as the opening of a passage) or a series of similar facts (such as alliances) or the triggering of similar and slightly different facts (such as wars). The specific facts (fields-milestones) are selected according to the importance and the element that there were milestones for Switzerland. Time periods and specific facts are in line, in general, with the classification of the previous literature $[1,4,2]$, but are adapted in an separate tracing that groups dispread elements of the bibliography. This does not mean that there are no other specific facts or other way to classify the time periods. Finally the time period after the year 1848 is a period we intend to study in a next research.

\subsection{Historical Overview}

The Swiss Confederation was founded in 1291 as a defensive alliance among three cantons (Uri, Schwyz and Unterwalden $^{8}$ ). In subsequent years more cities joined the original alliance of three. In early 1500 Swiss Confederation consisted of eight old cantons (Uri, Schwyz, Unterwalden, Zug, Luzern, Bern, Zurich, Glarus) and 5 new cantons (new entrants: Friburg, Basel, Schaffhausen, Appenzell, Solothurn). Cantons Aargau, Graubunden, St. Gallen, Turgau, Ticino, Vaud were added in 1803, Geneva, Neuchatel, Valais in 1815 and Jura in 1979. Swiss Confederation remained officially a member of the Holy Roman Empire until 1806 although jurisdictional autonomy occurred as defined by the Treaty of Basel in 1499 and full exemption from imperial power granted with the Peace of Westphalia in 1648.

The Constitution of 1848, which was amended in 1874, replaced the Confederation with a central federal government. By then it was a loose confederation (since 1515), with a short time interval that was defined as a federation by Napoleon from 1803 to 1815 . The religious conflict that took place in 1847 (where the Radicals-Protestants prevailed) led to the creation of a constitution with elements of federate republic, which included for example the possibility of a referendum at federal level. Cantonal referendum existed from past years and it was easy to be adopted at federal level. Among the federated cantons also was created common market by enacting the abolition of customs duties, single currency established and free movement of citizens between the cantons, as well [4]. In other words the principle of equality of civic rights ( appeared in ancient Greek federations, like the Achaean and Aetolian [58].

The sovereignty and neutrality of Switzerland have been honored extensively by the major European powers, and the country did not participate in any of the two world wars. The political and economic integration of Europe over the

8 Known also as the three forest cantons. past half century, and the role of Switzerland in numerous international organizations, has strengthened Switzerland's ties with its neighbors. However, the country did not officially become a United Nations member until 2002. Switzerland remains active in many international organizations but retains a strong commitment to neutrality [59].

Switzerland was founded in its modern form of federal state by the Constitution of 1848. The Constitution of Switzerland combines elements of direct democracy and a high degree of federalism. It installs significant potential in each canton and local government. Moreover it provides an unusually wide range of collective decision-making institutions in the three levels of government. In order to enable citizens to control the parliament and the executive power at federal level, the Swiss Constitution has established the constitutional initiative, compulsory and optional referenda.

An initiative for partial or even full constitutional amendment requires 100,000 signatures $^{9}$ ( $2.2 \%$ of voters in 1994), for optional referendum 50,000 signatures ${ }^{10}(1.1 \%$ of voters in 1994) or the request from at least eight of the total 26 cantons. Since the number of signatures required was reduced from $7.5 \%$ (1893) to $2.2 \%$ (1994) in the case of constitutional initiative and from $4.7 \%$ (1879) to $1.1 \%$ (1994) in the case the optional referendum, the number of initiatives and optional referenda that have been held increased substantially over the last one hundred years [9]. From 1971 to 2010 they have been conducted 94 optional referenda recalling respective laws and 121 initiatives. Of these 30 were approved and 11 respectively. Although the success rate is not significantly high, citizen participation is remarkable in comparison with the majority of other countries [4].

The main democratic polity institutions of Switzerland is the Federal Assembly consisting of two bodies elected directly by the people, the Council of States (Standerat) which has 46 representatives and the National Council (Nationalrat) numbering 200 deputies [4,60]. The Federal Assembly elects the Federal Council (Bundesrat), which implements executive power and has seven members with four-year incumbency and prime minister is designated every year, from one of the seven members of the Federal Council. At cantonal level there is a large dispersion of elements of direct democracy that vary from existence of direct-democratic assembly in some cantons such as Appenzell and Glarus, to pure representative democracy in other cantons. In some cantons the compulsory and optional referenda as representatives control tools include more topics than others, some established the possibility of initiative in addition to the constitutional initiative, and others didn't. Extremely highlighted are the referenda with financial subject. In some cantons it is possible for

9 Articles 138 and 139 of Swiss Constitution [61].

10 Article 141 of Swiss Constitution [61]. 
referenda (optional or compulsory) to take place by the voters with subject to set the level of taxation ${ }^{11}$, to approve of public deficits and to adopt the budget.

Direct democracy begins already from the 13th century $\mathrm{AD}$ in Switzerland. The Landsgemeinde, which was the assembly of citizens at cantonal level, appeared at Uri in 1231, forty years after the opening of the St Gotthard passage, in 1376 at Zug, in 1376 at Appenzell, in 1387 at Glarus, while at Schwyz and Unterwalden in early 1300. A similar assembly appeared at the League of the House of God, from the decade of 1360 . It is the current canton Graubunden [2]. The Glarus and Appenzell Innerrchoden maintain until today the assembly of all citizens, while for the rest cantons was abolished in the 19th and 20th century ${ }^{12}$.

During the second half of 14 th century the rural cantons formalized their assemblies, settled offices/buildings like Landammann, appointed councils with a clear legal status and produced written constitutions: in fact political states steadily emerged, sustained with well-organized structure. The widespread idea of democracy of cantonal assemblies (Landsgemeinde) was the result of these actions. But this traditional view was incorrect. At that time the cantonal assemblies related mainly to publicize and execute successfully the affairs of oligarchies than to encourage the equitable cooperation among citizens. Yet it is undeniable that under these circumstances political decisions could be more affected by the citizens (bottom up) than in what was happening in cities and in this way the political and social status of the leaders validated in a different way [62].

Among cantons there was a federal parliament (known as Tagsatzung or Diet) since 1412 and in each canton existed one cantonal parliament (known as Landsgemeinde). Reference [63] point out that the bottom up ${ }^{13}$ federations are more likely to emerge if the constituent members are more or less symmetrically in power and they face strong external enemies. Switzerland had powerful external opponent - the Habsburgs and the Burgundy - and showed a degree of symmetry in terms of power of constituents, excluding the fact that they were divided into urban and rural (geographical criterion of differentiation).

\section{Results}

\subsection{Passages}

Switzerland has the privilege to be a passage of the main trade routes of the Alps. There are three main groups of passages. To the west, there are passages of the Great St

11 That reflects essentially the degree of control over income from the citizens.

12 In Zug and Schwyz abolished in 1848 (with the implementation of the first Swiss Constitution), while in 1928 at Uri and at Nidwalden, Obwalden and Appenzell Ausserrhoden in the 1990s.

13 Because they come from the people's initiative.
Bernard and Simplon leading to Turin and Milan. To the east there are several paths (Julier, Septimer, Splugen, San Bernardino) leading to Como and Milan [1]. The third route crosses over Saint Gotthard passage (or St Gotthard), through the named Devil's Bridge (known as Teufelsbrucke) and is the most important passage among the rest. This passage was created only for commercial purposes since 1190 and resulted trigger economic development $[4,64]$ and to widen the horizons of people of areas that previously lived in geographical isolation ${ }^{14}$. The route through the passage of St Gotthard was the shortest trade route between Italy and Germany [64]. Local communities received fee when they provided animals with sleds in order to help traders with loads and travellers to move over the passage $[64,1]$. Continued commercial exchange of goods led to the economic specialization of Swiss communities. The main specializations were cattle and dairy products. An example of the development that occurred is the fact that Luzern was increased in size as it was in the 19th century [2], after having been given the opportunity to boost trade and transport of products through lakes [1]. Moreover the farmers in the small Swiss mountain areas had the opportunity to come into direct cooperation with the merchants, fact pretty rare for the rest Europe, as the knights came only in contact with merchants [64]. Noteworthy is also the fact that the canton Uri annexed the Leventina in 1478, the area was on the other side of the passage and this provided the basis for further military expansion of Swiss [2].

The trade route from Milan through Leventina, Uri and Lake Lucerne to Basel created new political alliances [1]. Canton Uri due to the creation of the St Gotthard passage gained official imperial freedom in 1231 and Schwyz in $1240[1,2]$. That meant that only the emperor had the right to control power in areas around the passage and to gain economic benefits from taxes and not local lords or dukes and nobles [4].

Trade was the second occupation of the inhabitants of the area, after agriculture. In addition to local commerce that had boosted due to rising population and economic growth, the contribution of the major trans-European trade routes ensured stable trade long-distance flows. In the major north-south route from the Alps to Italy, added the east-west route covering the shaft from Nuremberg and Poland at the northeast end and from Genoa and Barcelona to the southwest horizon. Traders crossed the Alps to get through these routes and local producers of silk, wool and linen contributed and benefited from these routes. Geneva became an entrepot and afterwards there were artisans who migrated to the North-Central Europe, following the dynamics of these routes [1].

The existence, around year 1200, of several important regional dynasties in the area north of the Alps set the stage

14 These areas were in valleys at high altitude. The bridge was built at an altitude of over 2000 meters. 
for future developments. The dukes of Burgundy disappeared after 1032 and the southern parts of the Duchy of Swabia came into the possession of the Duke of Zahringen in 1098. Their family ended in 1218, while the dynasty of Hohenstaufen (emperors and dukes of Swabia) was eliminated in 1250 with the death of Frederick II, and the death of Conradin and Manfred in Battles of Benevento and Tagliacozzo in 1266 [65]. The collapse of the main dynasties created opportunities for lower nobility - in this area the house of Swabia and the Counts of Hapsburg finally emerged as the new dynasties - and weakened public order and led to an increase in local violence and hostility. The imperial interregnum from 1250 until 1273 exacerbated such problems. In 1273 Rudolph was elected as emperor of the Holy Roman Empire, who had great acceptance due to war successes. He offered protection and free cooperation in the areas around the St Gotthard, until his death in 1291. The rise of Adolf in throne alarmed the rural mountain areas and they decided to sign an agreement for the common defence and protection of their privileges, fearing a new unstable interregnum. The three cantons of Uri, Schwyz and Unterwalden signed the agreement, known as Bundesbrief, and that was to be the beginning of democracy and the rule of Switzerland $[2,1]$.

\subsection{Alliances}

A pretty usual characteristic that can reasonably be observed in most aspects of the political (and not only) life of Switzerland are the alliances and cooperation and consent arising among the various parties, whether they are politicians, citizens, clergy or military formations. From the first time of appearance of Switzerland in 1291, the cooperation among three cantons showed that in this way they can achieve their goals (peace, defence, judicial independence). Gradually this alliance incorporated more cantons, totally 13 until $1500 \mathrm{AD}$. In 1830 , the rate was at 25 , which indicates the importance of cooperation. In modern times, cooperation and consent prevails at political level, where for example a law (in federal level) will not be voted by the Parliament without first the occurrence of cooperation among the political parties. That happens because, as it is widespread in Switzerland, if a law is not pleasing to the citizens, they can ask for its cancellation, through a referendum that may cause by collecting signatures. Even issues of national holidays and taxation as well, have resulted through years of negotiation and consent. Even monetary policy issues were addressed recently, in 2014 with the referendum on the repurchase of gold by the Swiss Central Bank.

A particular peaceful alliance among rural valleys/cantons of Uri, Schwyz and Nidwalden (part of the Unterwalden) signed and symbolizes the foundation of the Swiss Confederation. In August 1291, where signed the treaty, the actual text (known as Bundesbrief) contained a number of specificities and may have been written in 1309 or even later. It highlights some unusual features for alliance in the central Alps. The document includes support promises for defend and safeguard internal peace and furthermore oaths among cantons about not accepting judges outside their area. The prominent feature in this alliance/treaty is the parties (communities): homines, universitas, communitas of Uri, Schwyz and Nidwalden respectively, which are the political formations of the three rural valleys that have renewed an earlier treaty of 1250 [51]. Each of these entities had legal and corporate existence since 1291, as evidenced by stamps in the document and the requirements for imperial freedom they did $[1,62]$. By 14th century plurality of internal agreements/treaties took place in the cities/cantons/valleys that participated in the Swiss Confederation.

The alliance of Zurich (known as Zurcher Bund) at 1351, between Zurich and the three initial cantons was also important, when they pledged mutual support against the Habsburgs rulers [62]. In 1370 the six cantons (Zurich, Luzern, Zug, Uri, Schwyz and Unterwalden) signed a statute (known as Pfaffenbrief) where for the first time they took an oath about complete faith of citizens of communities to the regional administration and further they introduced a clause prohibiting clergy to appeal to ecclesiastical courts only but for spiritual and interior matters. The aim was, essentially, to reduce the misuse of church influence and the impunity in cases of serious crime and make ecclesiastical bodies accountable to local law and the courts. The cities imposed a tax on them and moreover the farmers refused to provide homage services imposed by clerics. With this treaty a common law established for the first time, converting what began as a network of peace alliances in a new peripheral power [1,51]. Furthermore, after the battle of Sempach in 1386, a treaty (known as Sempacherbrief) was signed in 1393, concerning military cooperation rules and distribution of the spoils $[2,1]$.

Gradually, knights and merchants gained political power and enjoyed the privileges of the city (cities, as well monasteries and rural communities, were quite autonomous once they answered only to the emperor after they had their own courts). As the internal autonomy increased, other groups sought active political participation (citizenship) as artisans (craftsmen) who organized in guilds. This is due to the location of the passages that were critical to the imperial policy (considering the relative autonomy granted to the area) in Italy, the weakness of the principal feudal dynasties and the high degree of cooperation in pastoralism/cattle-breeding that encouraged strong collective institutions [1]. In this way (and without using democratic means and especially modern ones) more and more people had the opportunity to participate in political life despite being under an aristocratic domination.

Reference [2] highlights that this trend for cooperation existed in these areas from the 12th century and included the so-called "culture of the herdsman". This contained the element of communalism and the extensive networking of communities and cooperative entities that determined the economic and social life. The Swiss communalism has been 
considered, at a point of view, to have survived as a custom of the early Germanic tribes. The culture of the herdsmen also included the characteristic of a lifestyle that was quasi-aristocratic, as they were free from feudal servitudes and as sign of liberty they bore arms and demanded 'honour' even from the nobles.

All the above do not mean that there weren't imperfections. Religious civil wars (in 1531 with the battle of the Kappel and in 1847 with the war of Sonderbund ${ }^{15}$ ) and rest civil wars (such as the "old" war of Zurich in 1436) occurred during the history of the country. In modern times, it has been observed respective form of alliance in the political field. From 1959 to 2001, there was a constant composition of the seven-member government of the country, concerning the representation of political parties. The form, also known as magic formula, composed of two members/deputies of Christian Democratic Party (CVP), two of the Liberal Party (FDP), two of the Party of Socialists (SPS) and one member of the People's Party-SVP-[66,4,1,2]. Another area that functions harmoniously and is the result of cooperation and consent is the coexistence of linguistic, religious and ethnic diversity $[52,4]$. The country has three official languages in widespread use (four national German, French, Italian, Romanian), a variety of ethnic groups and various religions [2].

\subsection{Military Tactics}

The Allies (Confederates) of the Swiss Confederation were very effective in their military operations. They left their mark on the military history of every nation in Central and Southern Europe and were the most significant military power in Europe for two centuries, from the 14th to the 16th. In combat tactics they used the formation of the soldiers in columns, where each one held a pike length of 5.5 meters. This military formation resembled the phalanx used by the ancient Greeks. After the war victories of Confederation in Morgarten (1315), Laupen (1339) and Sempach (1386) Confederates gained the reputation of persistent and invincible army and delivered a sensation of defeatism in generals and armies that were to fight with them, resulting enemies to reach in the battle without confidence [67]. No soldier especially mounted ones had a chance against the numerous sharp steel weapons (about 7.000 men per fight), which moved into highly disciplined formation, in a line of 100 meters long (stood some eighty to ninety men abreast) and a depth of seventy rows [68]. The success of the Confederates was, moreover, the result of the values developed within the army, such as courage, bravery, morale and discipline [67]. There followed a series of successful battles in Arbedo (1422), St. Jacob ${ }^{16}$ (1444),

15 Sonderbund can be translated as 'special alliance'

16 In this battle, the Swiss defeated but gained high reputation. It could be compared as the Battle of Thermopylae for the Greeks who became known for the bravery of warriors.
Grandson (1476), Morat (1476), Nancy (1477) and Frastanz and Dornach during the Swabian war (1499).

Alongside Switzerland played largely a European role, due to the presence of its mercenaries. In the late 15 th century, the reputation of the Confederation as a large pool of high skills mercenaries was established as a crucial and repeating factor for the policies that followed. Already in 1424 the Diet had accepted a proposal from Florence, in order to provide to the latter a large army of mercenaries.

They participated also in the victory of the Duke of Lorraine towards Charles the Bold, Duke of Burgundy, in 1477 in Nancy [62]. The military prestige of the Confederation had become too high. Recruitment and brokering of mercenaries had evolved into a significant business for many of the Confederates, they earned directly and indirectly. The military career and the business of mercenaries was a developing sector that reduced simultaneously the trade of cattle-breeding products to the south. In the late 16 th century, 50.000 men $(5 \%$ of the total population) had served in foreign regiments as mercenaries [1]. After the defeat at Marignano in 1515 the Confederation has consolidated its policy of neutrality, stopped expansive attack and signed peace with France in 1515 and the Habsburgs (known as Erbeinung) since 1511. The mercenaries however, continued to offer their services for several years after [1].

\subsection{Religion}

Switzerland from its early beginning adopted the Catholic Church. In early 1500 appeared a powerful reform movement in the Church, the Protestantism or Reformation. In the decade of 1520 the teachings of Zwingli began known in Zurich. He was a Swiss priest who had served as a priest in the battle of Marignano in 1515, was an enthusiastic reader of Erasmus ${ }^{17}$ and combined the humanist culture of the latter with the ability of the popular preacher and practice energy of an ecclesiastical reformer [69]. He criticized the services of mercenaries, proclaimed innovation in church (debated church authority/magisterium, celibacy for clergy, strict fasting) and found a ready audience to introduce his teaching since there were already voices, from early 1500 s, who wanted a better church. His preaching reached leading men, guildsmen and their families and Zurich's rural population, with result the city council to avoid Zwingli's possible prosecution, for his views [1].

The penetration of these new ideas was spread to rest Switzerland soon. The Diet decided in 1522 that cantons should avoid innovation in religion, but the implementation of this decision would remain in the jurisdiction of each canton separately ${ }^{18}$.

17. Holland philosopher humanist who had suggested religious reforms influenced by the renaissance practices $[2,4]$

18. It can be observed the democratic sense of the decision, something that didn't happen in countries such France, Spain and Italy where occurred 
An official religious meeting in Zurich, led to the adoption of Zwingli's ideas. Bern followed in 1528, as the Basel and Schaffhausen after two years [1]. Rural cantons remained mostly Catholic (Uri, Schwyz, Unterwalden) except Glarus ensuing double religion and Appenzell divided into two cantons (Appenzell Innerhoden and Appenzell Ausserrhoden) following separate religions ${ }^{19}$. The rural cantons that were the main providers of mercenaries did not adopt Reformation, as Zwingli had condemned this practice [70]. Luzern, Friburg and Solothurn remained Catholic. It is observed that cities-cantons, that had government contained by guilds, chose Protestantism and those where power controlled by the patricians, Catholicism was the first option, except from the city of Bern. Therefore, areas with a regime oriented to economic growth mainly chose Protestantism [70], which recalls the theory of Max Weber on Protestant ethics and contribution to development.

The expansion of Zwingli's Reformation led him to seek political and spiritual action in order to achieve further spread of the faith. But that intransigence led to open conflict. Catholic cantons allied, as those who supported the Reformation. In 1529 the magistrates of Zurich declared war against the Catholic cantons, however there was a treaty, known as First Landfrieden ${ }^{20}$, for troop withdrawal before the outbreak of hostilities, stating that both parties should avoid coercion in matters of faith and condominium areas would define by voting what faith will maintain.

The First Lanfrieden proved to be short lived, as the pressures on both sides to maintain their ideas to the rest escalated, to such point where the cantons supported the Reformation, such as Zurich, banned the sale of cereals to the Catholic cantons. Catholic cantons declared war and in October 1531 in the battle of Kappel, Reformation cantons suffered a crushing defeat where Zwingli killed. A treaty occurred in November of that year between the two parties in a moderate document, known as Second Kappeler Landfrieden, where there was an increase in privileges of Catholics, but at the same it was recognized the coexistence of the two faiths and each canton had the freedom to choose faith [1].

Bullinger was the successor of Zwingli in Zurich and the leading figure in Geneva was Calvin, who came as a refugee from France. Bullinger leaded the Reformation in

coordinate movement against the Reformation, the so called Counter-reformation.

19 Moreover it can be highlighted the fact that in Switzerland, division, not union, was the device by which the Swiss preserved their unity and peace, solving at the same time, as one of the few nations to accomplish this, their minority problems. Switzerland is not that it is a federation of three nationalities, but a federation of twenty-two states, the cantons, which, far from uniting its unequal national blocks, have divided them into so many small pieces that no single federal unit has a sizeable preponderance over any other. By this the essential precondition of every well functioning federation was created: a pattern which furnishes harmony and manageability by ensuring the physical and numerical balance of all participants on a small enough scale to enable even a weak central authority to execute its decisions. That led to the creation of cantonal consciousness instead of a federal one [74].

20 The Landfrieden can be translated as "Peace of the Country'.
Zurich for forty years until 1570, having sent more than 12.000 letters to ministers and lords throughout Europe, for political and religious issues. He was against the Anabaptists $^{21}$, a supporter of the execution of witches and his official declarations became the foundations of the Swiss Protestant Church [60]. Calvin, on the other side, was an educated Frenchman studied in Paris, published books with the most important the Christanae Religionis Institutio in 1536, managed the alliance with the Church of Zurich and emboldened the formation of a united Swiss Protestant Church [1,2].

The Reformation and Counter-Reformation 22 accelerated the massive migration. While Switzerland was generally an attractive haven for persecuted Protestants, Geneva as a francophone Cathedral and a place of the Reformation ${ }^{23}$, was particularly attractive to French Calvinists (Huguenots), many of whom were well networked experienced craftsmen. Continuously for more than two centuries, Geneva attracted a significant number of economically active and innovative layers of persecuted people. About 3000 French Protestants emigrated each year in Geneva from 1550 to 1720 . Innovation, in the production of goods, would be impossible without the initiative of refugees. These people brought not only skill and initiative but also commercial knowledge, capital, knowledge of international markets and reliable commercial and credit relations. They triggered sectors like trade silk and cotton, introduced the watchmaking industry in Geneva and initiated early capitalist traditions in production and trade which were outside the strict constraints of the guilds, such as lending and home industry $[71,4]$. Except the considerable watchmaking skills they established banks and pharmaceutical companies [72,4]. In refugees Protestants and their resourceful spirit is attributed, to some extent, the preparation of the broad foundations of industrial production, by promoting ways of organizing work and materials contributed to this production ${ }^{24}$ [71].

During the 17 th century the separation and polarization motivated by religious differences were obvious in every aspect of daily life in Switzerland, from politics to family life and habits of reading. In high conflict periods there were voices for abandonment of coexistence of the two faiths, such as in the 1620 s where the two sides did not showed willingness to reduce intolerance. A typical example is in the early 1630 where Schwyz proposed a division of condominium areas despite the joint control which existed until then. Nevertheless, by early 1585 there were voices for unity when Zurich and Bern sent a

21 Movement created in favour of the adult baptism

22 See footnote 18.

23After the Reformation, the Protestant teaching not only emboldened the accumulation of wealth, but defined it as a good practice, reflecting the hard work as the fulfillment of the duty of every man $[72,73]$.

24 Also in the 17th century, the so called protoindustrialisation began to spread, where producers of low quality goods, mainly textiles, provided raw materials and basic tools in poorer rural households that had surplus manpower, applying the putting-out system, the precursor of wage labour $[1,2]$. 
delegation in Luzern for negotiations and Catholic cantons sent in turn delegation for initiating peaceful solutions negotiations. There was an agreement in 1632, on how to negotiate religious matters without however to be applied widely. The continuous tendency for separation, on the one hand, and the desire to keep the unity, on the other hand, shaped the religious culture of that era.

In early 1650s the rural development of non-urban Swiss areas (which had begun during the thirty-year war to serve Germany needs) stopped and prices began to fall and combined with the deterioration of the climate, urban areas started to protect investors who had lent money to farmers. The inter-religious (Protestant and Catholic) alliance of peasants, which occurred due to the devaluation of the currency from the Berne side, proceeded to revolt (having as a symbol William Tell from the past) which suppressed from inter-religious coalition of the rest parties (citizens of cities). Revolutionists were peasants, from rural areas of Luzern, Bern, Solothurn and Basel. In other words, in front of economic issues they ignored religious differences. Through this occasion it was fostered, to an extent, the tendency for religious coexistence.

The second religious civil war took place at the end of 1655 (known as the First War of Villmergen) between Zurich and Schwyz, was of short duration and occurred mainly because the cantons of the Catholic cantons had larger representation in Diet and the Protestant ones had smaller representation, even if the latter had more wealth and population than Catholic ones. The conflict ended with the treaty known as the Third Landfrieden in January 1656. The result was the function two more parliaments, one for Catholic cantons and one for Protestant cantons, as de facto institutions, along with the operation of the de jure parliament (Diet) in Baden.

After the war of 1656, especially from the side of Protestants emerge more flexible religious ideas, such as less dogmatic approach to religion that should respect individual freedom of conscience, influenced by the rapid spread of the ideas of Descartes and the pastor Tronkin. A new practice adopted by the teachers of the Reformation in 1675 which had the consent as its central idea. While this idea had the acceptance of the Protestant Parliament, it was fully implemented in 1706. However some old disagreements between the Prince-Abbot of St. Gallen and the major Protestant areas of Toggenburg led to another conflict (known as the Second War of Villmergen) in 1712. Zurich and Bern helped the latter areas and Protestants won for the very first time [1]. With the treaty, known as Fourth Landfrieden, in 1712 it was appointed peace of Aarau, where the Catholic cantons were losing some privileges in the administration of the condominium areas, but the Abbot of St. Gallen regained the administration towards Toggenburg with the obligation to protect the Protestants. By 1715 the Confederation was in complete inner peace and the whole previous procedure of conflicts provided stability [1] and supported effectively the creation of the modern Swiss state [2]. The recent conflict between the two sides took place in 1847 in Bern, where a (secret) alliance of seven Catholic cantons defeated against the radical Protestants. Catholics had created the alliance known as the Sonderbund to protect their sites from rising pressures from Protestants. When the latter informed for the Sonderbund, the proceeded to conflict where prevailed, leading the country to the creation of the federal republic [2].

It is noteworthy that from 1828 until today the election of bishops of the Catholic cantons takes place with open democratic processes and the participation of laity in the voting, which is not anywhere else appears in the world and is characterized as a modern Tagsatzung-Diet $[2,4]$.

\section{Discussion}

\subsection{Formation of the Swiss Macroculture}

There were several factors that contributed to the creation of the Swiss federal republic. The opening of the St Gotthard Pass was one of them, also the alliances among cantons, the war tactics and religion, without exclude perhaps other factors that are not included in this research.

Having divided the periods of historical evolution of Switzerland into four (1st:1200-1291, 2nd: 1291-1386, 3rd: 1386-1515 4th: 1515-1848), we can observe the following findings. In the first period there is an increase in economic activity and an initial familiarity with the existence of political and economic prerogatives in the areas/cantons which, afterwards, will be named Switzerland. It could be considered as an inner shock, which comes from the opening of the St Gotthard passage, which gave privileges (report directly to the emperor and not to the local nobility) in Uri in 1231 and Schwyz in 1240. The expansion of commerce and the importance that the area acquired as a hub of European trade routes has increased the confidence of the inhabitants of these cantons and the tendency for freedom and involvement in public affairs, through bounded rationality, i.e. through transferring these values in the political field. In the year 1271 the first cantonal parliament (Landsgmeinde) was launched in Uri in early form. After that the three forest cantons allied in 1291 in order to protect their privileges. This can be considered as a result of their tendency to have confidence and to assert their presence in the political map through cooperation. Consequently, an economic factor (the St Gotthard passage) which boosted business, commerce, production, economic development, contributed to democracy to an extent initially, since spurred the tendency for cooperation and created the first parliament. In early 1300s the cantonal parliaments of Schwyz and Unterwalden was created, and although they didn't have the form as it has today a parliament, political decisions could be most affected by the citizens than in other areas at that time.

In the second period it can be observed the practice of the alliance as a means of maintaining peace in the area and to ensure the defence and judicial independence and efficiency 
(treaties: Bundesbrief, Pfaffenbrief, ZurcherBund). Consecutive alliances and treaties, spurred a similar culture, where after any treaty/agreement the cooperation among cantons extended a step further (e.g. with Sempacherbrief treaty that arranged military issues). Cooperation and consent are values deriving through alliances among cantons and began to embed to citizens of the cantons of the Confederation. In other words, the consent that existed at the political level began to apply, slowly however, on the people.

The third period shows the appearance of systematic and effective practice of combat practices of allies. They used the formation of the soldiers in columns, where each one held a pike length of 5.5 meters and this military formation resembled the phalanx used by the ancient Greeks. The consecutive military victories of Confederation created the reputation of persistent and invincible army of allies. The warriors moved in highly disciplined formation, and their success was the result (among others) of the values developed within the army, such as courage, bravery, morale, equality and discipline. Also the national consciousness had risen. These values passed gradually in other aspects of life such as economic activity and political events. These values are united with the values of inclusivity, democratic coexistence, self-confidence, tendency for freedom that firstly appeared and the value of cooperation that occurred in the second period. A macroculture was created in this way, imbued with these values that led to the creation of a common identity ${ }^{25}$, with main characteristic the tendency for freedom and having rights to control the power. Aftermath examples of these values, was the creation of parliaments gradually in all cantons and the creation in 1412 of the federal parliament (known as the Diet or Tagsatzung), which didn't have a key role as cantonal parliaments, but it was a precursor of the current parliament in Switzerland.

The fourth period contains the new religion of Protestantism/Reformation that divides the Confederation in two sides. Zwingli and Calvin were the main leaders of the new religion and were soon to be conflicts between cantons that adopted the Reformation and cantons continued to embrace Catholicism. There were four main religion conflicts from 1531 to 1847 , however, characterized by a tendency to reach an agreement at a time after each battle and actually to make a step forward

25 The identity was also influenced by folk heroes/legends like William Tell and Arnold Wilkenried. The first was among those who attended the first oath of Bundesbrief in 1291 and then resisted to the Hapsburg ruler named Gessler. Specifically, Tell did not bow the hat that Gessler hung in the square of Aldorf (capital of Uri) something that all residents had to do. To save the life of Tell, Gessler asked him to make a shot with the crossbow (as Tell was famous archer) to an apple that will put on the head of his son. The Tell properly targeted the apple but he had ready a second bow to throw in Gessler in case of failing to target the apple. Gessler imprisoned Tell for this thought, but the latter escaped and killed Gessler, acquiring tremendous reputation that lasted centuries and was a symbol of freedom. Wilkenried was a hero in the war of Sempach in 1386, where he gave his life by falling in the middle of the battle in order to receive as much as possible javelins of his opponents and create space for his comrades to get on. Indeed, they won the battle and the act of Wilkenried was decisive $[51,1]$. towards the harmonious co-existence and the emergence of democratic institutions. Table 2 summarizes the institutions arising after every civil religious conflict.

The conflict was avoided in 1529 , as there was troop withdrawal agreement (First Landfrieden) before the outbreak of hostilities, stating that they should avoid coercion in matters of faith and condominium areas would define by voting what faith will sustain. The first battle was in Kappel in 1531, where Catholics won and there was an increase in their privileges, but at the same they recognized the coexistence of the two faiths and each canton had the freedom to choose faith. Two more religious civil wars in 1656 and 1712 followed. Through all the above conflicts, political practice and culture of consent of the country shaped to some extent and supported effectively the creation of the modern Swiss state. The continuous tendency for separation, on the one hand, and the desire to keep the unity, on the other hand, shaped the religious culture of that era. In 1650, before the two wars of 1656 and 1712, there was a conflict between an interreligious alliance of Protestant and Catholic peasants who revolted because of currency devaluation by the Berne side, and an interreligious coalition of the citizens of cities, with the latter to prevail. This means that in front of financial matters they ignored religious differences. Through this occasion it was fostered, to some extent, the tendency for religious coexistence. The First War of Villmergen in 1655/1656 between Zurich and Schwyz occurred mainly because the cantons of the Catholic cantons had larger representation in Diet and the Protestant ones had smaller representation, even if the latter had more wealth and population than Catholic ones. The conflict ended with the Third Landfrieden in January 1656 and the result was the function two more parliaments, one for Catholic cantons and one for Protestant ones, as de facto institutions, along with the operation of the de jure Diet in Baden. After the war of 1656 emerged more flexible religious ideas especially on the part of Protestants, such as respect for individual freedom of conscience. A new practice adopted by the teachers of the Reformation in 1675 which had the consent as its central idea. While this idea had the acceptance of the Protestant Parliament, it was fully implemented in 1706. However some old differences led to the Second War of Villmergen in 1712. Protestants won for the very first time and peace of Aarau was appointed where the Catholic cantons lost some privileges in the administration of the condominium areas, but the Abbot of St. Gallen regained the administration towards Toggenburg with the obligation to protect the Protestants who were the majority. By 1715 the Confederation was in complete inner peace and the whole previous procedure of conflicts provided stability. The religious conflict that took place in 1847 (where the Radicals-Protestants prevailed) led in 1848 to the creation of a constitutional democracy with federal elements, which included for example the possibility of a referendum at federal level. 
Table 2. Religion civil wars and religious institutions emerged

\begin{tabular}{|c|c|c|c|c|}
\hline Year & War & Treaty & Winners & $\begin{array}{c}\text { Democratic institutions/ } \\
\text { values }\end{array}$ \\
\hline 1529 & avoided & First Landfrieden & - & Democratic choice of religion \\
\hline 1531 & Battle of Kappel & Second Landfrieden & Catholics & $\begin{array}{c}\text { Recognition of the different religions } \\
\text { Free choice of faith }\end{array}$ \\
\hline 1650 & $\begin{array}{c}\text { Inter-religious alliance of } \\
\text { peasants }\end{array}$ & - & $\begin{array}{c}\text { Inter-religious alliance of } \\
\text { cities }\end{array}$ & $\begin{array}{c}\text { Trend for harmonic religion } \\
\text { coexistence }\end{array}$ \\
\hline 1656 & First War of Villmergen & Third Landfrieden & Catholics & $\begin{array}{c}\text { Creation of two more parliaments } \\
\text { for each religion) parallel to the } \\
\text { confederate one }\end{array}$ \\
\hline 1712 & Second War of \\
\hline 1847 & Villmergen & Fourth Landfrieden & $\begin{array}{c}\text { Harmonic religion coexistence } \\
\text { Respect to different religions } \\
\text { Consent }\end{array}$ \\
\hline
\end{tabular}

Source: Authors' process

Table 3. Values obtained from the fields-milestones and final compose of the democratic macroculture

\begin{tabular}{|c|c|c|c|}
\hline Field-milestones & Values/Institutions & & Democratic macroculture \\
\hline Opening of trade passages & $\begin{array}{c}\text { Self-confidence } \\
\text { Tendency for liberty } \\
\text { Tendency to participate in the commons } \\
\text { Inclusivity } \\
\text { Democratic coexistence } \\
\text { First parliament in Uri }\end{array}$ & \multirow{4}{*}{ Through bounded rationality } & \multirow{4}{*}{$\begin{array}{c}\text { Democratic institutions } \\
\text { Equality } \\
\text { Tendency to participate in the } \\
\text { commons } \\
\text { Discipline } \\
\text { Respect to otherness/diversity } \\
\text { Democratic resolve of disputes } \\
\text { through referenda } \\
\text { Consent } \\
\text { Harmonic democratic coexistence of } \\
\text { different religions } \\
\text { Create parliaments } \\
\text { Establish federal democratic } \\
\text { constitution }\end{array}$} \\
\hline Alliances & $\begin{array}{c}\text { Cooperation } \\
\text { Consent }\end{array}$ & & \\
\hline War/military tactics & $\begin{array}{c}\text { Equality, Courage, Bravery } \\
\text { Morale, Discipline }\end{array}$ & & \\
\hline Religion & $\begin{array}{c}\text { Respect to otherness/diversity } \\
\text { Tendency for harmonious religion consistency } \\
\text { Consent } \\
\text { Create parliament } \\
\text { Establish federal democratic constitution and } \\
\text { federal referendum } \\
\text { Democratic choice of religion }\end{array}$ & & \\
\hline
\end{tabular}

Source: Authors' process

Figure 3 shows in chronological order the fields-milestones that shaped macroculture of Switzerland through the values/institutions they created.

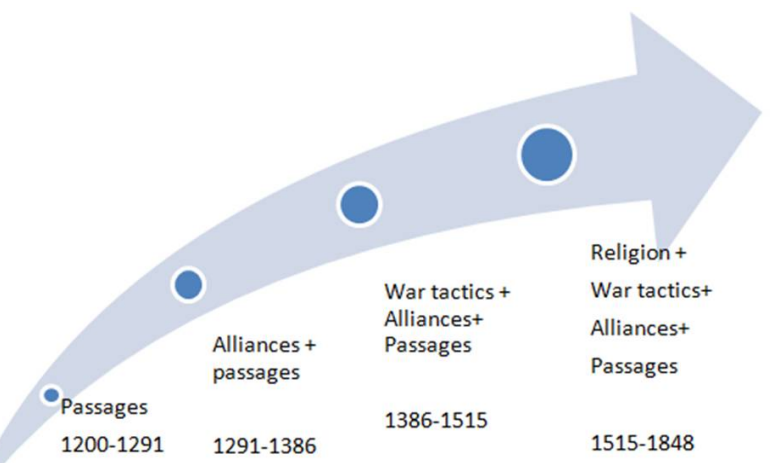

Source: Authors' process

Figure 3. Fields-milestones of Swiss historical evolution in chronological order
The circles represent the different elements of a new macroculture, resulting in a field-milestone during the first and second period and strengthened through diffusion to other sectors in the third period and have been consolidated into a new mutually supported macroculture in the fourth period. The values/institutions are presented in Table 3.

Through the four fields-milestones (passages, alliances, war tactics and religion) values and institutions such as inclusivity, cooperation, consent, equality, discipline, respect to diversity, establishment of democratic constitutions and referenda were created. These values were transferred through bounded rationality in the political field and created the Swiss democratic macroculture, through a continuous and long synthesis lasting for centuries.

No religion, dynasty or language ever joined Swiss citizens as the original foundation of modern Switzerland. The Swiss identity appeared in the history of Swiss areas around the year 1500. This identity was built through the historical evolution and remains to date, with main 
characteristics the complexity and diversity in language, culture and religion and the harmonious coexistence of them, fact that differentiates it from the most other European countries. Political innovation and flexibility found seminal ground at medieval times, in the year 1250 . This flexibility made it possible to form loose but stable networks of alliances between cities and rural areas from 1250 to 1386 . The loose Confederation of 1386 was the precursor of the Old Confederation that was forged from 1386 to 1513 and lasted until 1798 . This identity from the moment that was established had a significant effect on subsequent developments, because it could adapt and revive as a foundation for political and economic survival and success in turbulent 19th and (especially the) 20th century. And after 1800 the emerging nation formed with natural boundaries and idealized national unity.

\section{Conclusions}

An alliance of three areas/cantons, held in 1291, was meant to be the beginning of a large alliance that would list 26 cantons, and continues to exist to this day. The main feature resulting from this long course is the adoption of elements of direct democracy in conjunction with the federal system components in large scale, as a state option, and the successful functioning of the economy.

The elements used in order for Switzerland to achieve longevity and democratic and economic prosperity are the research objectives of this research. Questions such what are the institutions (e.g. collective or individual organisations, informal or formal institutions, values, norms and beliefs) which led to the adoption of direct democracy processes in governance since the first centuries of existence of the alliance where then became the Federation of Switzerland, is in the first line of investigation in this research. The main contribution to the research area is the fact, that this study uses the tool of macroculture, aiming to explain the emergence of Swiss democracy. This application gave us the opportunity to highlight some fields-milestones which are analyzed, for the first time, as a mixture of components that co-shaped a democratic macroculture.

We can conclude from the previous sections, composing the various elements, that there were at least four fields-milestones that created values and institutions and over time synthesized a democratic macroculture and finally a democracy. The fields-milestones are the commercial passages, alliances, military tactics and religion.

The values derived from the previous fields are noteworthy: inclusivity, cooperation, consent, equality, discipline, respect to diversity, establishment of democratic constitutions and referenda are some of them. When these were transferred to the political field, then it was created democracy in Switzerland with its modern form, through a long-term process.
Swiss citizens now have more power than politicians but do not speak to each other in the same language. It turns out that Protestants or Catholics, residents of Luzern or Geneva had more in common than differences.

We can also infer, that the entrepreneurial spirit that characterizes the Swiss has been inherited from the emergence of Protestantism and the attracted Protestant refugees from France to Geneva who had high technical expertise. The neutrality (i.e. not participating in WW I and WW II) has been inherited from the practice of neutrality that followed the defeat in the battle of Marignano. The importance of individual areas such as the existence of commercial business is a result of the business expansion triggered by the creation of the St Gotthard passage.

Recommendations for future research could be the investigation of other fields-milestones, such as sports or any other area that may be created institutions that led to democracy. Finally the application of the mathematic model in a case study is one of our future goals.

\section{REFERENCES}

[1] C. H. Church, R. C. Head. A Concise History of Switzerland, Cambridge University Press, (Cambridge Concise Histories), New York, 2013.

[2] J. Steinberg. Why Switzerland? Cambridge University Press, Second Edition, UK, 1996.

[3] W. Linder. Swiss Democracy, Possible Solutions to Conflict in Multicultural Societies, Third Edition, Palgrave McMilan, Hampshire, Great Britain, 2010.

[4] D. Bewes Diccon. Swiss watching, inside the land of milk and honey, Nicholas Bradley Publishing, London, 2012.

[5] L. Feld, G. Kirchgässner. Sustainable Fiscal Policy in a Federal System, Switzerland as an example, Working Paper No 16, Center for Research in Economics, Management and the Arts, (Crema), Basel, 2005.

[6] L. Feld, G. Kirchgässner. On the effectiveness of debt break, the Swiss Experience, Working Paper No 21, Center for Research in Economics, Management and the Arts. (Crema), Basel, 2006.

[7] L. Feld, G. Kirchgässner, C. A. Schaltegger. Fiscal Federalism and Economic Performance: Evidence from Swiss Cantons, Philipps-Universität Marburg, Fachbereich Wirtschaftswisse nschaften Nr. 20, Marburg, 2004.

[8] L. Feld, G. Kirchgässner, J. A. V. Fischer, The Effect of Direct Democracy on Income Redistribution: evidence for Switzerland, Economic Inquiry Vol. 48, No. 4, 817-840, 2010.

[9] L. Feld, M. Savioz, Direct Democracy Matters for Economic Performance: An Empirical Investigation, Kyklos, 50, 507-538, 1997.

[10] D. North. Institutions, Institutional Change and Economic Performance, Cambridge University Press, Cambridge, 1990. 
[11] N. Kyriazis, M. E. Economou. Property Rights and Democratic Values in Bronze Age and Archaic Greece, Munich Personal Repec Archive (MPRA), 2012.

[12] N. Kyriazis, T. Metaxas, M. E. Economou. 'War for profit: corsairs, institutions and decentralized strategy', Defense and Peace Economics, vol...(Forthcoming), 2016.

[13] E. Abrahamson, J. C. Fombrun. Forging the iron cage: Interorganisational networks and the production of Macroculture. Journal of Management Studies, 29, 175-194, 1992.

[14] E. Abrahamson, J. C. Fombrun. Macrocultures: Determinants and Consequences. Academy of Management Review 19 (4), $728-755,1994$.

[15] C. Jones, J. Hesterly, S. Borgatti.. A General theory of Network Governance; Exchange conditions and social mechanisms. Academy of Management Review 22 (4), 911-945, 1997.

[16] C. Ratner. Macro Cultural Psychology, A Political Philosophy of Mind, Oxford University Press, 2012.

[17] Oxford Advanced Learner's Dictionary, meaning of value, Online available from: http://www.oxfordlearnersdictionaries.com/

[18] R. D. Blackwell, P.W. Miniard, J. F. Engel, Consumer Behavior, Harcourt, Inc, Orlando Florida, 2001.

[19] C. Camerer, A. Vepsalainen. The economic efficiency of corporate culture. Strategic Management Journal, 9, 115-126, 1988.

[20] O. Williamson. Comparative economic organization: The analysis of discrete structural alternatives. Administrative Science Quarterly, 36 (2), 269-296, 1991.

[21] O. Williamson. Markets and Hierarchies: Analysis and Antitrust Implications. Free Press, New York, 1975.

[22] A. G. Almond, S. Verba. The Civic Culture: Political Attitudes and Democracy in Five Nations, second ed. Sage Publications, California, 1989.

[23] R. Putnam. Making Democracy Work. Princeton University Press, Princeton, 1993.

[24] M. Granovetter. Problems of explanation in economic sociology", in: Nabria, N., Eccles, R.G. (Eds.), Networks and organizations: Structure, forms and action. Harvard: Harvard Business School Press, Harvard, pp. 25-26, 1992.

[25] N. Lazaric. Organizational routines and cognition: An introduction to empirical and analytical contributions, Journal of Institutional Economics, 7 (2), 147-156, 2011.

[26] J. Vromen. Routines as Multilevel Mechanisms. Journal of Institutional Economics, 7 (2), 175-196, 2011.

[27] R. M. Solow. History and Economics. American Economic Review, 75 (2), 328-331, 1985.

[28] M. Daunton, Rationality and institutions: Reflections on Douglas North. Structural Change and Economic Dynamics, 21, 147-156, 2010.

[29] D. North. Structure and change in economic history. New York: W.W. Norton \& Co, 1981.
[30] D. North. Structure and performance: The task of economic history. Journal of Economic Literature, 16 (3), 963-978, 1978.

[31] T. Amemiya. Economy and Economics in Ancient Greece, first ed. Routledge, London, 2007.

[32] I. Morris. The Athenian economy twenty years after the ancient economy. Classical Philology 89 (4), 351-366, 1994.

[33] B. Schefold. The applicability of modern economics in forms of capitalism in antiquity, some theoretical considerations and textual evidence, Journal of Economic Asymmetries, 8 (1), 131-164, 2010.

[34] K. Polanyi. Aristotle discovers the economy, in: Dalton, G., (Ed.), Essays of Karl Polanyi: Primitive, Archaic, and modern economies. Beacon Press, Boston, 1957.

[35] C.S. Humphreys. Anthropology and the Greeks. Routledge \& Kegan Paul, London, 1978.

[36] I. M. Finley. Economy and Society in Ancient Greece. Viking Press, New York, 1982.

[37] G. Bitros, D. A. Karayannis, Values and institutions as determinants of entrepreneurship in ancient Athens. Journal of Institutional Economics, 4 (2), 205-230, 2008.

[38] E. Cohen., Athenian Economy and Society: A Banking Perspective. Princeton University Press, Princeton, 1997.

[39] D. Engen. Ancient greenbacks, Athenian owls, the law of Nicophon, and the Greek economy, Historia, 54 (4), 359-381, 2005 .

[40] G. Halkos, N. Kyriazis., The Athenian economy in the age of Demosthenes. European, Journal of Law and Economics, 29, 255-277, 2010.

[41] N. Kyriazis. Financing the Athenian state: Public choice in the age of Demosthenes, European Journal of Law and Economics, 27 (2), 109-127, 2009.

[42] H. C. Lyttkens. A Rational-actor perspective on the origin of liturgies in ancient Greece. Journal of Institutional and Theoretical Economics, 153, 462-484, 1997.

[43] J. Ober. Democracy and Knowledge. Princeton University Press, Princeton, 2008

[44] J. Ober. The instrumental value of others and institutional change: An Athenian case study. Princeton/Stanford Working Papers in Classics, Version 1.0, Stanford University, Stanford, 2010.

[45] J. Ober. The Rise and Fall of Classical Greece, (The Princeton History of the Ancient World) Princeton University Press, New Jersey, 2015.

[46] N. Kyriazis, T. Metaxas, Theodore. Bounded Rationality and Institutional Change, Evolutionary and Institutional Economics Review, 7(1):1-19, 2010.

[47] N. Kyriazis, X. Paparrigopoulos. The birth of democracy: Values in war and politics in classical Greece, in Hermann, P., (Ed.), Democracy in the Theory and Action. Nova Publishers, New York, pp. 277-287, 2011.

[48] H. Simon. Models of Bounded Rationality, (1 and 2), MIT Press, Cambridge, Massachusetts, 1982.

[49] H. Simon. Bounded Rationality and organisational learning. 
Organisation Science, 2 (1), 125-13, 1991.

[50] N. Kyriazis, T. Metaxas. The emergence of democracy: a behavioural perspective Munich Personal RePEc Archive Paper No. 47146, 2013.

[51] W. Lardner. The History of Switzerland, from B.C. 110 to 1830, Forgotten Books, Classic Reprint Series, The Bradley company publishers, New York, 2012.

[52] G. Fossedal Gregory. Direct democracy in Switzerland, Transaction Publishers, New Brunswick (U.S.A.) and London (U.K.), 2002.

[53] B. Kaufmann, R. Bóchi, N. Braun. The IRI (Initiative \& Referendum Institute Europe) Guidebook to Direct Democracy in Switzerland and beyond, editor Paul Carline in cooperation with Federal Department of Foreign Affairs, General Secretariat, Presence Switzerland, 2010.

[54] K. Kobach. The Referendum: Direct Democracy in Switzerland, Aldershot: Dartmouth, 1993.

[55] A. H. Trechsel and H. Kriesi. Switzerland: the referendum and initiative as a centerpiece of the political system, in: $\mathrm{M}$. Gallacher and P.V.Uleri, The Referendum Experience in Europe, McMillan Press Ltd, 1996.

[56] K. Kobach. Recent Developments in Swiss direct democracy, Electoral Studies 12:4, pp. 342-365, 1993.

[57] Federal Department of Foreign Affairs, Federal Administration of Switzerland, Online available from https://www.eda.admin.ch/content/dam/PRS-Web/Dokumen te/en/auf-dem-weg-zum-bundesstaat-1815-1848_EN.pdf

[58] N. Kyriazis, M. E. Economou. Economy and Democracy an analytical history of democracy from its birth to today, Enalios, Athens, Greece (in greek), 2015.

[59] Central Intelligence Agency - CIA. The World Factbook 2015, Switzerland introduction, Online available from https:/www.cia.gov/library/publications/the-world-factbook /

[60] K. Maycock. Switzerland, the essential guide to customs \& culture, Series - Culture Smart!, Kuperard, London, 2010.

[61] Federal Constitution of the Swiss Confederation, Online available from: http://www.admin.ch/ch/e/rs/1/101.en.pdf

[62] R. Sablonier. The Swiss Confederation, in New Cambridge
Medieval History, Volume VII. c. 1415-c. 1500, chapter 25, edited by Christofer Allmand, Cambridge University Press, 2008.

[63] M. L. E. Economou, N. Kyriazis, T. Metaxas, The institutional and economic foundations of regional protofederations, Economics of Governance, Volume 16, Issue 3, pp 251-271, 2015.

[64] G. Bryant. Medieval Movements and the Origins of Switzerland, RAIN Magazine, Vol XIV, Number 1, 1991.

[65] S. Tucker. A Global Chronology of Conflict: From the Ancient World to the Modern Middle East, ABC Clio, Santa Barbara, California, 2010.

[66] T. David, A. Mach. Institutions and Economic Growth the Successful Experience of Switzerland (1870-1950), Research Paper 2006/101, United Nations University, UNU-WIDER World Institute for Development Economics Research, Helsinki, Finland, 2006.

[67] C. W. C. Oman. The art of war in the middle ages A.D. 378-1515. Cornell University Press, 1885.

[68] C. Allmand. War, in New Cambridge Medieval History, Volume VII. c. 1415-c. 1500, chapter 25, edited by Christofer Allmand, Cambridge University Press, 2008.

[69] P. Schaff. History of the Christian Church, Volume VIII: Modern Christianity. The Swiss Reformation. Grand Rapids, MI: Christian CLassics Ethereal Library, Electronic Bible Society, Dallas, 2002.

[70] C. Basten, F. Betz, Marx Vs Weber, Does Religion Affect Politics and the Economy?, Working Paper No1393, European Central Bank, Frankfurt, 2011.

[71] A. Voskuhl. Androids in the Enlightenment: Mechanics, Artisans, and Cultures of the Self, University of Chicago Press, 2013.

[72] J. Breiding, Swiss Made: The Untold Story Behind Switzerland's Success, Profile Books, London, 2012.

[73] M. Weber. The Protestant Ethic and the Spirit of Capitalism, Lambrakis Press Group, Special Edition for the newspaper To Vima (in greek), 2010.

[74] L. Kohr. The Breakdown of Nations, Routledge Keegan and Paul, reprinted in 2001 by Horizon Research Publishing, 1957. 